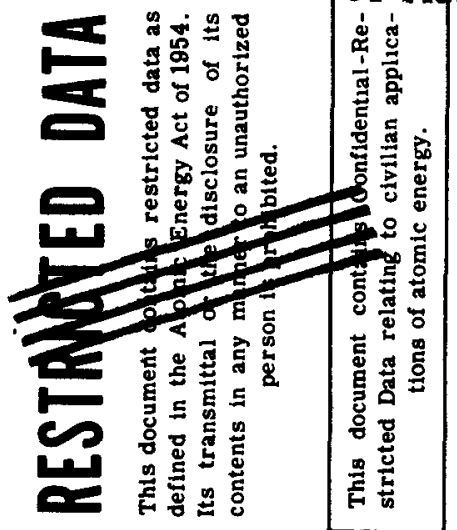

LEGAL NOTICE

This report was prepared as an account of Government sponsored work. Neither the United States, nor the Commission, nor any person acting on behalf of the Commission:

A. Makes any warranty or representation, express or implied, with respect to the accuracy, completeness, or usefulness of the information contained in this report, or that the use of any information, apparatus, method, or process disclosed in this report may not infringe privately owned rights; or

B. Assumes any liabilities with respect to the use of, or for damages resulting from the use of any information, apparatus, method, or process disclosed in this report.

As used in the above, "person acting on behalf of the Commission" includes any employee or contractor of the Commission to the extent that such employee or contractor prepares, handles or distributes, or provides access to, any information pursuant to his employment or contract with the Commission.

\title{
THE VITRO MANUFACTURING COMPANY
}

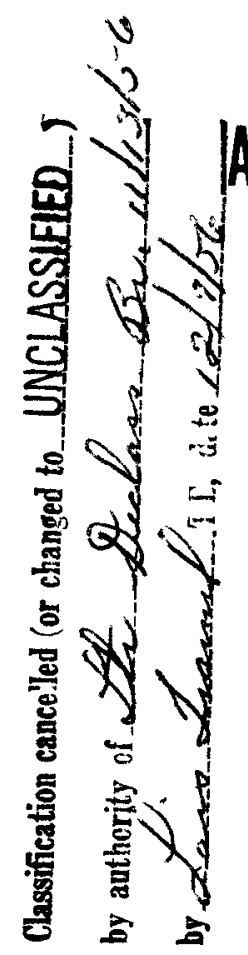

\author{
NYO- 1154 \\ PROBLEMS OF REFINING URANIFEROUS \\ RESIDUES \\ TECHNOLOGY FEED MATERIALS
}

Progress Report No. 20

Contract: $\quad \mathrm{AT}-(30-1)-1241$

Period: $\quad$ December, 1952

Date: January 15, 1953

Submitted by:
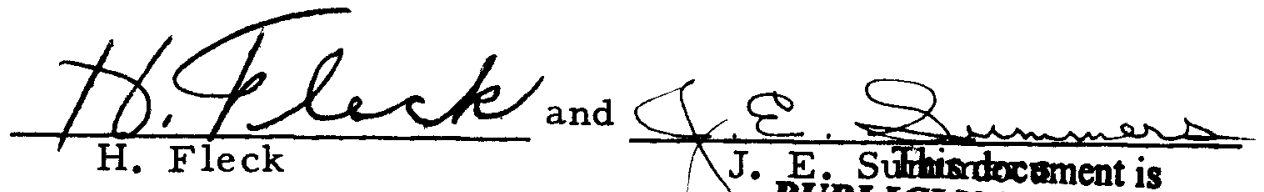
PUB Sulfiondoxment is

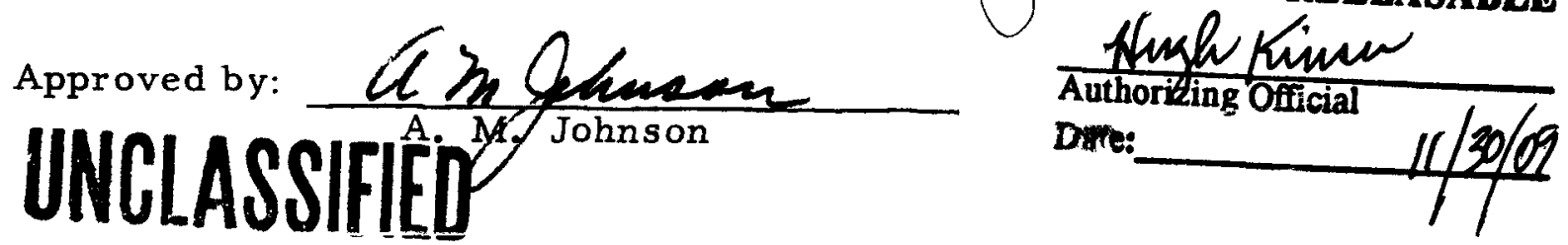
thak kimer Approved by: 4 h hewen 


\section{DISCLAIMER}

This report was prepared as an account of work sponsored by an agency of the United States Government. Neither the United States Government nor any agency Thereof, nor any of their employees, makes any warranty, express or implied, or assumes any legal liability or responsibility for the accuracy, completeness, or usefulness of any information, apparatus, product, or process disclosed, or represents that its use would not infringe privately owned rights. Reference herein to any specific commercial product, process, or service by trade name, trademark, manufacturer, or otherwise does not necessarily constitute or imply its endorsement, recommendation, or favoring by the United States Government or any agency thereof. The views and opinions of authors expressed herein do not necessarily state or reflect those of the United States Government or any agency thereof. 


\section{DISCLAIMER}

Portions of this document may be illegible in electronic image products. Images are produced from the best available original document. 
NYO -1154

PROBLEMS OF REFINING UR $A$.NIFROUS RESIDUES

TECHNOLOGY - FEED MATERLALS

\section{A. SUMMARY}

\section{GENERAL}

1. Scope of Program

As of December 1, 1952, the Research Program consisted of the following projects:

Digestion and Refining of C-Slag and Other Residues (Project No. I)

Investigate the applicability and reilincment of various procedures for the treatment and digestion of C-Slags and other uraniferous residues for recovery of aranium values, placing emphasis on methods adaptable to the Canongburg Plant with minimum of change of equipment.

Refining and Processing of Sodium, Carbonate Residues (Project No. 5)

Investigate method of recovery of uranium from various residues, resulting from sodium carbonate digestion of miscellaneous uranium bearing niaterials, to reduce the U308 content of the residue below $0.05 \%$. 
$\mathrm{NYO}-1154$

Page: 3

2. Previous Reports:

\begin{tabular}{|c|c|c|c|c|c|}
\hline NYO-1145 & March & 1952 & - Progress & Report & No. 11 \\
\hline NYO-1146 & April & 1952 & 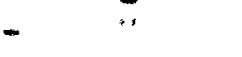 & 7 & No. 12 \\
\hline $\mathrm{NYO}-1147$ & May & 1952 & $*$ & " & No. 13 \\
\hline NYO-1148 & June & 1952 & .2 &. & No. 14 \\
\hline NYO-1140 & July & 1952 & $n$ & 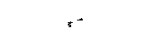 & No. 15 \\
\hline NYO- 1150 & Auguet & 1952 & - & $\because$ & No. 16 \\
\hline NYO-1151 & September & 1952 & . & & No. 17 \\
\hline NYO-1152 & October & 1952 & $"$ & ; & No. 18 \\
\hline $\mathrm{NYO}-1153$ & November & 1952 & - & , & No. \\
\hline
\end{tabular}

PROJECT STATUS

3. Research Project - Digestion and Refining of C-Slags and Other Residues

During the program of experimentation on high grade feed material to determine whether or not the Vitro high grade feed material could be adapted to processes of a more economical nature as compared to the present established purification process, it was found that cid insolubles resulting from bydrochloric or sulfuric acid digest of Har haw Press Cake would be extremely difficult, if not imposable, to separate from the digest slurry by filtration. Experiments were conducted to determine whether or not calcination of the $r$ aw material at elevated temperatures prior to acid digestion would have a beneficlal sintering effect, thus expediting filtration of acid insolubles. 
$\mathrm{NXO}-1154$

4. Research Project - Digestion and Refining of Sodium Carbonate Reaidues

Experimental work concerning pitchblende carbonate re sidues was intensified. An extensive program was initiated to scan various processes and procedures for their applicability to pitchblende carbonte residues.

Two types of pitchblende carbonate residues are under consideration. The first trpe assays approximately $1.6 \%$ U308 and the second $0.7 \%$ U308. The two types vary somewhat in Iron and aluminum content in adition to uranium concentration. Digestion procedure concerning mineral acids were reviewed for both types with intent to finalize digestive data and to obtain final comparative data on chemical bebavior during acid digention of both residues.

Experiments were conducted to determine whether or not the residues were amenable to organic solvent extraction techniques, based on the theory that solubilized iron may be succes sfully extracted from acld media by di-ethyl ether when iron is present as the chloride lon. By extraction of solubllized iron and subsequent neutralization of the aqueou phase using ammonium hydroxde it was hoped to obtain a precipitate which would be acceptable as an end product.

The possibility of ferrocyanide selective precipitation of uranfum from acid solution was constdered $n$ an additional series of experiments. The purpose of experimentation w: to effect selective prectpitation of the uranyl ion using potasium ferrocyanide from an acid digest filtrate. Precipitation wa to be made after reduction of solubilized iron to the ferrous atate to avoid the imultaneous precipitation of contaminating "prussian blue." 
NYO-1154

Page: 5

Additional experiment were conducted based on the theory that ferrous iron will not precipitate as a hydroxide if complexed by the presence of sufficient quantities of ammonium chloride. In this manner. It was hoped that reduction of iron, addition of ammonium chloride, followed by neutralization of an acid digest filtrate of pitchblende residue * with aqua ammonis would result in quantitative precipltation of solubilized uraniura as a precipitate of high urablum content with a minimum of contamination.

Experiments were conducted surveying the possibility of extracting solubilized urantum from a miner 1 acid digest filtrate of the pitchblende restdues a uranous phosphate by reduction of the pregnant solution with sodium hydrosulfite at low pH values, Preliminary data indicates that this may be a successful procedure in so far as the type of pitchblende carbonate restidues assaying . $07 \%$ U 308 is concerned.

The Indicated succes of uranous phosphate precipitation led to the Initiation of experiments designed to determine optimum conditions of precipitation aecessary for quanti tative extraction. A preliminary investigation of wodtim hydroculfite requiremente, the most desirable pH of precipitation. and the benefits of the addition of excess $\mathrm{PO}_{4}$ ion was completed. 
NYO-1154

Page: 6

B. DIOESTION AND REFINING OE C-OXIDE FND OTHER XESIDUES

Research Project No: 1

Research Supervisor: J. E. Summers

\section{LABORATORY OPERATIONS}

5. Futration of Acid Insolubles Resulting From A Hydrochloric er Sulfuric Digest of harshaw Press Cake

During the process of experimenting on Vitro bigh grade feed materials to determine the feastbility of shorter and more economical means of refining these materials. It was noted that cid insolubles resulting from a hydrochloric or sulfuric cefd digest of Harshaw Press Cake exhibited lime characteristics and a consequence were almost impossible to fllter. The normal means of preparing Hiar shaw Press Cake for production purification consists of process of drying and calcination at temperatures approximating $1100^{\circ} \mathrm{F}$, in order to remove volatile organic contaminant such as tributyl phosphate. The fired material, after comminution is processed in the usual manner. Acid insolubles resulting from a production digent of Press Cake are not normally removed from the digest slurry until after neutralization of the digest with sodum carbonate. This procedure carried out in the established Vitro process is ontisfactory in effecting maximum filtration of insolubles since the $y$ apparently exhibit different characteristics in the presence of alkall. However, if the proposed treatment coneisting of hydrochloric acid digestion and precipitation of ammonium 
NYO- 1154

di-uranate from a clarified filtrate followed by calcination of the di-uranate precipitate to a black oxide at $800^{\circ} \mathrm{C}$ is to be effective as regards press cake, it is necessary to determine some mean of expediting removal of acid insolubles from the acid digest slurry. Samples of Harshaw Press Cake were taken from production lots and calcined at varying temperatures up to $1600^{\circ} \mathrm{F}$ to determine if elevated temperature 8 would have a sintering effect on the raw material which would eliminate the formation of slimes or gel during acid digestion. Completed experimental data indicates that If the material is calcined at $1400^{\circ} \mathrm{F}$ for one hour prior to acid digestion, the acid insolubles resulting from hydrochloric acid digestion may be easily and readily removed by normal means of filtration without the as sistance of artificlal filtering alds. Filtration of the insoluble restdue was rapid and easily washed uranium free. Acid insolubles resulting from acid digestion of the intered material contained les: than .05\% U308. Complete experimental data may be found in Table 1.

In general, with reference to experimentation on optimum procedures for the refining of high grade feed materials, sufficient data has been eccumulated on the laboratory level to carry such procedures into the pilot or semi-works phase. Unless unknown circumetances should indicate additional laboratory development on the materials under consideration, or similar materials, no further experimentation is presently planned. 
NYO-1154

Page: 8

C. REEINING AND PROCESEING OE SODIUM CARBONATE RESIDUES

Research Project No: 5

Rezearch Supervisor: J. K. Surriers

LABOR TOEY OPERATIONS

5. Mineral Acid Digestion of Sodium Carbonate Xesidues Resulting as a By-Product of Pitchblende Purification

Pitchblende carbonate residues may be categorically divided into two groups for experimentation. These two groups represent the entire stockpile of this type of sodium carbonate residues at the Vitro installation. The first group of residues contin approximately $1.60 \%$ U308, plus aluminum $\$$ the principal contaninant with a proportionately maller arnount of iron and silica and vanadium. This group of residue is identified a Pitchblende Carbonate Residue ' $A$ ' . The second group of residues has uranium content of $0.69 \%$ U308 and contains fron a the major contaminant with proportionately smaller amount of aluminum, silica, vanadium, etc. The second group of residues is identified as Pitchblende Carbonate Residue' Since the two groups of residues contain proportionately different amounts of uranium and variable quantities of aluminum and iron the $y$ are considered separately and experimental data is recorded in this manner. 
NYO-1154

Pitchblend Re sidue

Additional experiments concerning rineral acid digestion of this residue were completed. In general, all data obtained tends to confirm previous experinientation of the same nature. 100 gram samples of the dryed residue were pulverized to less than 100 mesh and dige ted in sulfuric acia at pH values ranging from .0 to 0.5 in the presence of I\% (w/v) sodium nitrate. Tine of digestion was from 1 - 4 hours at a temperature range of $80^{\circ} \mathrm{C}-90^{\circ} \mathrm{C}$. f cid insolubles resulting frori the procedure were voluminous, of a slimy nature, and very difficult to filter. The uraniur. level of sulfuric acta digest insolubles remained well in excess of maximun spectications for discard residues. containing more than . $30 \%$ U308. This data tend to confirr. previous diat and we may assume that a sulfuric acia treatment is undesirable and inapplicable to this residue.

Digestion of this residue in a hydrochloric acid media was somewhat more successful. $100 \mathrm{gram}$ samples of the dryed residue were pulverized to less than 100 mesh, slurried in water at ratio of $4: 1$ and digested in commercial hydrochloric acid at $\mathrm{pH}$ values ranging from 0.0 to 0.5 in the presence of $0.5 \%$ (w/v) sodium chlorate for periods of time extending to four houx at temperature $x$ anging between $80^{\circ} \mathrm{C}-90^{\circ} \mathrm{C}$. This procedure, as indicated from previous data, will be satisfactory in solubilizing contained uraniur: and the digest slurry will lend itself to removal of acid insolubles by filtration. The uranium content of the insoluble residue resulting from the HCl digest treatment contained les than . $05 \%$. 4308 , and may be considered satis factory for a discard residue. Insolubles were found to represent 6 to $8 \%$ of the original volume. Representative data may be found in Tuble II - 
Pitchblende Estate $\mathrm{E}$

Additional experiments were conducted concerning mineral acid digestion of this residue. Sulfuric acid was again found to be an unsutisfactory digest media. $100 \mathrm{graru}$ samples of the $x$ w material were dryed, pulverized to less than 100 mesh, slurried in water at ratho of 4:1 and digested in sulfurtic acid at phi value ranging from 0.0 to 0.5 for periods of time up to faur hour at temperatures ranging between 80 and $90^{\circ} \mathrm{C}$. The insoluble residue resulting from this treatment was easily removed by fil tration, but wa found to contain uraniur considerabiy in excess of discard specifications. The residue approximated $75^{\text {gi }}$ of the original volume and hat an verage as ay of . 26\% U308. However, hydrochloric acid digestive techniques, as in the case of Pitchblende Residue $\xi *$, were found to be entirely satistactory as regards successful extraction of the contained uranium. $100 \mathrm{gram}$ samples of the dryed material were pulverized to les than $100 \mathrm{mesh}$, slurried in water at ratio of $4: 1$ and digested in comriexcial hydrochloric acid a pH $0.0-0.5$ in the presence of $0.5 \%(w / v)$ sodium chlorate at $80^{\circ} \mathrm{C}$ for pertods of time up to four hour w. atid insolubles averaged approximately $10 \%$ of the original volumn and contained les than. $05 \%$ U308. Calcination of the raw material prior to digestion did not markedly alter the chemical characteristics of the residue during mineral cid digestion. Representative data mad be found in Table $\mathbf{L}-\mathbf{B}$.

6. Refining of Pitchblende Residues by a Process of Hydrochloric facid Digestion and Di-Ethyl Ether Extraction of Iron

Experiments were concluded on pitchblende residues bised on the theory that iron $x$ ay be extracted as a soluble chloride fron: acid solution by the use of an non-miscible organic solvent 
NYO-1154

Page: 11

such as di-ethyl ether. Uraniurr is not extracted as the chloride ion. It was theorized, that if this were feasible the extraction of ferric chloride from a bydrochloric acid digest filtrate of pitchblende carbonate residues using ether, followed by a precipitation of uranium from aqueous phase might result in a precipitate which would be an acceptable product. It was demonstrated by preliminary experimentation that such a procedure would be impractical. It wa immediately evident that iron was present in such large quantities that ether would have to be used in such volume as to make the procedure economically impractical. In addition, the presence of large quantities of sulfate and phosphate ion did not permit adequate extraction of iron even when large quantities of ether were consurned. f further difficulty that developed throughout the proces was the tendency of the ether phase to gel due to the presence of large quantities of siliceous matter which passed into the organic phase. No further experimentation of this nature is planned.

7. Precipitation of Uranium From a Hydrochloric Acid Digest Filtrate of Pitehblende Resldues Using Potassium Eertocyanide

Scoping experimento were completed designed to determine if uranium could be selectively and quantitatively precipitated from a bydrochloric acid digest filtrate of pitchblende carbonate residues by the addition of potassium ferrocyanide. The reaction sould procede in the following mianner:

$$
\mathrm{Fe}(\mathrm{CN})_{6}+2 \mathrm{UO}_{2} \longrightarrow\left(\mathrm{UO}_{2}\right)_{2}\left[\mathrm{Fe}(\mathrm{CN})_{6}\right]
$$

The resultant precipitate could then be processed to sodiur. di-uranate by the use of sodiun hydroxide as follows:

$$
\begin{aligned}
\left(\mathrm{UO}_{2}\right)_{2}\left[\mathrm{Fe}(\mathrm{CN})_{6}\right]+ & 6 \mathrm{NaOH} \longrightarrow \mathrm{K}_{4}\left[\mathrm{Fe}(\mathrm{CN})_{6}\right]+3 \mathrm{H}_{2} \mathrm{O} \\
+ & \mathrm{Na}_{2} \mathrm{U}_{2} \mathrm{O}_{7}
\end{aligned}
$$


NYO-1154

Page: 12

In order to avoid a simultaneous precipitation of the ferric salt of fer rocyanic acid it was necessary to prepare the solution for precipitation by reducing iron in solution to the ferrous state. It was hypothesized that iron could be reduced in the presence of uranium, without reduction of uranium, by the addition of sodium thlosulfate catalyzed by the adition of amall quentity of copper. Experiments conducted in this manner on bydrochloric acid digest filtrates of pitchblende carbonate residues were only partially successful. Although it was possible to remove uranium using this technique it was not possible to obtain quantitative reduction of solubllized iron. This was probably die to exposure to air as the solution was agitated. As a result, uranium precipitation was accompanied by the precipitation of "prussian blue. Contamination of the resultant precipitate was such that the procedure was ineffectual. Uranium content of the residue did not exceed $4-5 \%$ U308. However, further investigation is indicated and additional experimente may be conducted to determine if this technique may be developed into a successul means of separation.

8. Precipitation of Uranium From A Hydrochloric Acid Solution of Pltchblende Residues Using Agua Ammonia Áfter Complexing Reduced Iron With Ammonium Chloride

Experiments were completed based on the theory that iron, when reduced to the ferrous state and complexed with sufficient ammonium chloride, will not precipitate in the presence of ammonium bydroxide. Normally. ammonta produces in neutral solutions an incomplete precipitation of ferrous hydroxide. The reaction moves to the left when excess ammonium chloride is present, as follows:

$\mathrm{FeCl}_{2}+2 \mathrm{NH}_{3}+2 \mathrm{H}_{2} \mathrm{O}$ $\rightleftharpoons \mathrm{Fe}(\mathrm{OH})_{2}+2 \mathrm{NH}_{4} \mathrm{Cl}$ 
NYO-1154

It was askumed that should thi procedure prove feasible as regards hydrochloric acid digest filtrate of pitchblende residues, uranium could be precipltated as ammonium di-uranate without the usual contamination from precipitated iron. The resultant residue would then be easily purified to an acceptable end product. Filtrates from hydrochloric cid digestive procedure were used for experimentation. Solubilized Iron was reduced to the ferrous state by the addition of sodium thiosulfate. Amm:onium chloride wadded in exces of theoretical requirement\$. The pregnant solution was neutralized to pH 6.0 with ammonium hydroxide. Only partial success was indicated. A Llustrated by other experimentation, reduc tion of solubilized iron to the ferrous state was far frorr: complete, probably due to exposure to air during agitation. The residue resulting from neutralization witk aqua ammonta was heavily contaminated by both iron and aluminum. Uranium content of the precipitate did not exceed $3.5 \%$ U 308 . The economics of this procedure and the poor results of preliminary experimentation do not indicate that additional experiments will be practical.

9. The Precipitation of Uranous Phosphate From the Hydrochloric Acid Digest Filtrate of Pltchblende Carbonate Residues

Preliminary experiments were initiated to estimate the feasibility of adapting pitchblende carbonate residue to a proces of uranous phosphate precipitation from a clarified bydrochloric acid digest filtrate by reduction of the uranyl ion with sodium bydrosulfite. The $\mathrm{P}_{2} \mathrm{O}_{5}$ content of the residues is sufficiently high to effect complete precipitation of uraniurr. without further addition of phosphates. Preliminary experiments indicate a possibility of a practical application. Since this type of a precipitation is influenced by soluble aluminum content of the pregnant Liquor and aluminum content of $P_{1}$ chblende Carbonate "A "and " $B$ " Is not the same, results for the two different types of pitchblende residues are considered separately. 
Eitchblende Carbonate Residue " $A^{*}$

$100 \mathrm{gram}$ samples of this residue assaying $1.6 \% 0308$ were dryed, pulverized to les than 100 mesh, slurried in water at a ratio of $4: 1$ and digested in commercial bydrochloric acid at pH 0.5 in the presence of $0.5 \%(w / v)$ sodium chlorate for one hour at $80^{\circ} \mathrm{C}$. cid insoluble were removed by filtration and the clarified filtrate used for experinentation. Sodium bydrosulfite was added to the pregnant liquor in excess of theoretical requirements at pH 2.0 . The precipitate that formed wa both voluminous and difficult to filter, indicating that disportionate amount of solubilized aluminum with resultant complexing activity. Analysis of the clarified filtrate indicated a discard effluent assayng from 0.025 - . 10 U308. Recovery, of course, was unsatisfactory ranging from $60-90 \%$ total yleld. The uranous phosphate residue was heavly contaminated with aluminum and averaged only about $3-4 \%$ U308. It is not immediately apparent that pitchblende residue " $A$ " will be arrenable to this treatment. However, additional experiments are indicated and a survey of the possibility of successful reduction using metallic iron or sluminum is planned. Preliminary data may be found in Table III-th.

Pltchblende Carbonate Residue "B:

Preliminary experiments were completed on the precipitation of uranous phosphate from a pregnant hydrochloric acid digest filtrate of pitchblende residue " $\mathrm{B}^{\prime i}$. Initial experiment: indicated successful and satisfactory extraction of colubilized uranium. $100 \mathrm{gram}$ samples of residue " $\mathrm{B}$ " were slurried in water at a ratio of 4:1, digested in $\mathrm{HCl}$ at pH 0.5 for one hour at $80^{\circ} \mathrm{C}$, oxidized with $1 \%(w / v) \mathrm{NaClO}_{3}$ and filtered. The clarified filtrate was reduced with $\mathrm{Na}_{2} \mathrm{~S}_{2} \mathrm{O}_{4} \cdot 2 \mathrm{H}_{2} \mathrm{O}$ at pH 2.0 and the resultant precipitate separated by filtration. Discard effluents averaged $.005 \%$ U 308 indicating a total yield of $95 \%$. 
$\mathrm{NYO}-1154$

Page: 15

Due to the satisfactory nature of preliminary data series of experiments was conducted to obtaln preliminary data on optimum pH of precipitation, sodium hydrosulfite requirements and phosphate ion requirements. $100 \mathrm{gram}$ samples of Residue " $B$ " were slurried in water at atio of 4:1, digested in $\mathrm{HCl}$ at $\mathrm{pH} 0.5$ for one hour at $80^{\circ} \mathrm{C}$, oxidized with $1 \%(w / v) \mathrm{NaClO}_{3}$ and filtered. The insoluble residues were acceptable for discard. Filtrates were used for experimentation. Uranous phosphate was precipitated from the pregnant solution over a pH range of 0.5 2. 0 using quantities of $\mathrm{Na}_{2} \mathrm{~S}_{2} \mathrm{O}_{4} \cdot 2 \mathrm{H}_{2} \mathrm{O}$ ranging from $2.0 \mathrm{gm}$. - $8.0 \mathrm{gm}$. In some instances, additional phosphate was added in the form of $\mathrm{Na}_{3} \mathrm{PO}_{4}$ prior to precipitation. In general, results are encouraging although nothing conclusive may be stated at this time. An extensive program of experimentation is planned to correlate all factor leading to satisfactory procedure. Preliminary data i presented in Table III $-\mathrm{B}$. 
$N \times-1154$

Page: 16

E XIEITS

$16: 17.16$ 
$T \cdot B \perp, Y I$

HYDROCHLORIC A CID DICESTION OFH KSH W PRESS CAKE

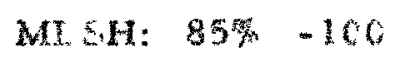

EXPERIMENT NUMB

\begin{tabular}{|c|c|c|c|c|c|c|}
\hline & 1 & $\underline{2}$ & $\underline{3}$ & 4 & 5 & 6 \\
\hline Temperatur of Calcination $\left({ }^{\circ} \mathrm{C}\right)$ & 1100 & 1200 & 1300 & 1400 & 1500 & 1600 \\
\hline veight of Sample (gm.) & 500 & 500 & 500 & 500 & 500 & 500 \\
\hline Weight of $\mathrm{H} 20$ (gm.) & 2000 & 2000 & 2000 & 2000 & 2000 & 2000 \\
\hline Weight of $\mathrm{HCl}$ (gm.) & 425 & 425 & 425 & 425 & 425 & 425 \\
\hline Digest Tirre (hr.) & 3 & 3 & 3 & 3 & 3 & 3 \\
\hline Digest Termerature $\left({ }^{\circ} \mathrm{C}\right)$ & 80 & 80 & 80 & 80 & 80 & 80 \\
\hline pH of Digestion & 0.0 & 0.0 & 0.0 & 0.0 & 0.0 & 0.0 \\
\hline Filtration Time (min.) & $\begin{array}{l}\text { Non- } \\
\text { Silterable }\end{array}$ & $\begin{array}{c}\text { Non- } \\
\text { Filterable }\end{array}$ & 48.0 & 8.5 & 8.0 & 8.5 \\
\hline cid Insolubles $\left(g r_{*}\right)$ & $\ldots$ & $\cdots$ & 214 & 208 & 205 & 207 \\
\hline cid Insolubles (菏 U308) & - & -- & .15 & .050 & .055 & .035 \\
\hline
\end{tabular}


$\mathbf{T}+\mathbf{B L E} \mathbf{I I}-A$

MINER, L ACID DIGESTION OF PITCHBLENDE CALOUN T TESIDUS

$455 \%$ Y: $1.6 \%$ U 308

Weight of 5 armple (gm)

Weight of $\mathrm{H} 2 \mathrm{O}(\mathrm{gm} \cdot)$

treight of $\mathrm{H}_{2} \mathrm{SO}_{4}(\mathrm{gr}$.

Weight of $\mathrm{HCl}$ (gm.)

Time of Digest $\left(h x^{*}\right)$

pH of Digest

Temperature of Digestion $\left({ }^{\circ} \mathrm{C}\right)$

${ }^{+}$cid Insolubles (gm.)

cid Insoluble (U308)

\section{MSARX Y: $1.6 \%$ U 308}

EXPERIMENT NUMBEL

\begin{tabular}{|c|c|c|c|c|c|c|c|}
\hline \multirow[b]{2}{*}{$\underline{1}$} & \multirow[b]{2}{*}{$\underline{Z}$} & \multirow[b]{2}{*}{3} & \multicolumn{3}{|c|}{ EXPERIMENT NUMBEL } & \multirow[b]{2}{*}{$\underline{7}$} & \multirow[b]{2}{*}{8} \\
\hline & & & $\underline{4}$ & $\underline{5}$ & $\underline{6}$ & & \\
\hline 100 & 100 & $100^{2}$ & 100 & 100 & 100 & 100 & 100 \\
\hline 400 & 400 & 400 & 400 & 400 & 400 & 400 & 400 \\
\hline$\cdots$ & $\ldots$ & $\sim$ & $-\cdots$ & 165 & 155 & 165 & 165 \\
\hline 280 & 270 & 275 & $\angle 75$ & $-\infty$ & -- & - & - \\
\hline 1 & 2 & 3 & 4 & 1 & 2 & 3 & 4 \\
\hline 0.0 & 0.5 & 0.20 & 0.15 & 0.0 & 6.5 & 0.20 & 0.14 \\
\hline 80 & 80 & 80 & 80 & 80 & 80 & 80 & 80 \\
\hline 6.0 & 8.0 & 6.5 & 7.2 & 130 & 132 & 130 & 135 \\
\hline .050 & .032 & .032 & .055 & .31 & .33 & .33 & .33 \\
\hline
\end{tabular}


TABLE II-B

MINERAL ACID DIGESTION OF PITCHBLENDE CARBONATE RESIDUE: B

$55 \times 0.69 \%$ U 308

\begin{tabular}{|c|c|c|c|c|c|c|c|c|}
\hline & & & & $\mathrm{EXE}$ & $1 E N T$ & MOES & & \\
\hline & $\underline{1}$ & 2 & 3 & 4 & 5 & $\underline{6}$ & 7 & 8 \\
\hline Weight of Sample (gm.) & 100 & 100 & 100 & 100 & 100 & 100 & 100 & 100 \\
\hline Height of $\mathrm{H} 20$ (gri.) & 400 & 400 & 400 & 400 & 400 & 400 & 400 & 400 \\
\hline eight of $\mathrm{HCl}(\mathrm{grn})$, & 235 & 235 & 220 & 230 & - & -- & -- & -- \\
\hline Weight of $2 \mathrm{SO}_{4}(\mathrm{gm}$ ) & $-\infty$ & $-\infty$ & - & $\cdots$ & 145 & 132 & 135 & 135 \\
\hline Time of Digest $\left(h x_{0}\right)$ & 1 & 2 & 3 & 4 & 1 & 2 & 3 & 4 \\
\hline pH of Digest & 0.0 & 0.0 & 0.5 & 0.35 & 0.0 & 0.55 & 0.35 & 0.30 \\
\hline Temperature of Digest $\left({ }^{\circ} \mathrm{C}\right)$ & 80 & 80 & 80 & 80 & 80 & 80 & 80 & 80 \\
\hline cid Insolubles (gm.) & 6.5 & 8.5 & 10.0 & 9.2 & 75.5 & 75.0 & 74.6 & 76.2 \\
\hline Acid Insolubles (U308) & .032 & .055 & traces & .055 & .26 & .31 & .22 & .28 \\
\hline
\end{tabular}




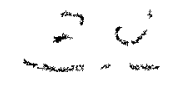

TADIN III-

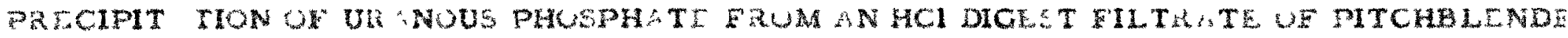

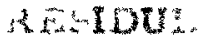

A.5. X: 1.6\%

SXPEAMENT NUALE:

\begin{tabular}{|c|c|c|c|c|}
\hline & 1 & $\underline{2}$ & 3 & $\underline{4}$ \\
\hline Wight of Sanple (gm.) & 100 & 100 & 100 & 100 \\
\hline Weight of $\mathrm{H}_{2} \mathrm{O}\left(\mathrm{gm}^{\circ}\right)$ & 400 & 400 & 400 & 400 \\
\hline eight of $\mathrm{HCl}(\mathrm{gx})$. & 270 & 270 & 270 & 270 \\
\hline pH of Digestion & 0.5 & 0.5 & 0.5 & 0.5 \\
\hline Time of Digest $(\mathrm{hr} \cdot)$ & 1 & 1 & 1 & l \\
\hline Temper ture of Digestion $\left.{ }^{a} \mathrm{C}\right)$ & 80 & 80 & 80 & 80 \\
\hline pkl of Precipitation & 2.0 & 2.0 & 2.0 & L. v \\
\hline $\mathrm{Na}_{2} \mathrm{~S}_{2} \mathrm{O}_{4} \cdot 2 \mathrm{H}_{2} \mathrm{O}$ aded $(\mathrm{gn})$. & 2,0 & 3.0 & 4.0 & 5.0 \\
\hline fesidue $(\mathrm{gm})$. & 33.6 & 31.5 & 31.0 & 35.0 \\
\hline Hesidue $(\mathrm{U} 308)$ & 3.0 & 3.86 & 3.64 & 3.75 \\
\hline Discard fflumen (P308) & 0.10 & .049 & .046 & $.0<4$ \\
\hline Becovery (rit) & 06.0 & 80.4 & 8.6 & 90.6 \\
\hline
\end{tabular}


$T$ T BLE III - B

PRECIPITATION OF URANOUS PHOSPHATE FROM AN HCI DIGEST FILTRATE OF PITCHBLENDE

RESIDUE "B"

ASSAY: $\quad 0.69 \%$ U308

Weight of Sample (gm.)

Weight of $\mathrm{H}_{2} \mathrm{O}(\mathrm{gm}$.

Weight of $\mathrm{HCl}(\mathrm{gm}$.

pH of Digestion

Time of Digest (hx.)

Temperature of Digestion $\left({ }^{\circ} \mathrm{C}\right)$

pH of Precipltation

$\mathrm{Na}_{2} \mathrm{~S}_{2} \mathrm{O}_{4} \cdot 2 \mathrm{H}_{2} \mathrm{O}$ Added (gm.)

$\mathrm{Na}_{3} \mathrm{PO}_{4}$ Added (gm.)

Residue (gm.)

fie aldue (\% U308)

biscard Effluent (\% U308)

Recovery $(\%)$

\section{EXPERIMENT NUMBER}

\begin{tabular}{|c|c|c|c|c|c|c|c|c|c|}
\hline 1 & $\underline{2}$ & & 4 & $\underline{5}$ & 6 & 7 & 8 & 9 & 10 \\
\hline 100 & 100 & 100 & 100 & 100 & 100 & 100 & 100 & 100 & 100 \\
\hline 400 & 400 & 636 & 400 & 400 & 400 & 400 & 400 & 400 & 400 \\
\hline 220 & 220 & 28 & 220 & 220 & 220 & 220 & 220 & 220 & 220 \\
\hline 0.5 & $0.5^{\mathrm{m}}$ & 0.5 & 0.5 & 0.5 & 0.5 & 0.5 & 0.5 & 0.5 & 0.5 \\
\hline 1 & 1 & 1 & 1 & 1 & 1 & 1 & 1 & 1 & . \\
\hline 80 & 69 & 80 & 80 & 80 & 80 & 80 & 80 & 80 & 30 \\
\hline 0.5 & 40 & 1.5 & 2.0 & 0.5 & 1.0 & 1.5 & 2.0 & 2.0 & 2.0 \\
\hline 2.0 & 2.8 & 2.0 & 2.0 & 5.0 & 5.0 & 5.0 & 8.0 & 2.0 & 4.0 \\
\hline- & -- & $\cdots$ & - & - & $\cdots$ & $\cdots$ & $\ldots$ & 2.0 & 2.0 \\
\hline 10.0 & 10.0 & 11.0 & 10.5 & 10.5 & 10.5 & 11.0 & 11.0 & 10.0 & 11.0 \\
\hline 3.30 & 4.24 & 6.22 & 6.40 & 3.75 & 6.25 & 6.10 & 6.30 & 6.45 & 6.15 \\
\hline .061 & .046 & .006 & .001 & .049 & .01 & .0001 & .001 & .007 & .00 \\
\hline 39.0 & 54.0 & 94.0 & 99.0 & 51.0 & 90.0 & 99.9 & 99.0 & 93.0 & 95.0 \\
\hline
\end{tabular}


THIS COPY TO BE ROUTED TO:
1.
2.
3.
4.
5.
6.
7.
8.
9.
10. Job Files

No. COPY NO 4/6A

DATE January 15, 1953

SUBJECT NYO-1154 - Problems of Refining Uraniferous Residues - Technology Feed Material - Progress Report No. 20

To Mr.F.M. Belmore

FROM

A. M. Johnson

BEFORE READING OR HANDLING THIS

DOCUMENT, SIGN AND DATE BELOW

SI GNATURE

DATE

S I GNATURE

DATE

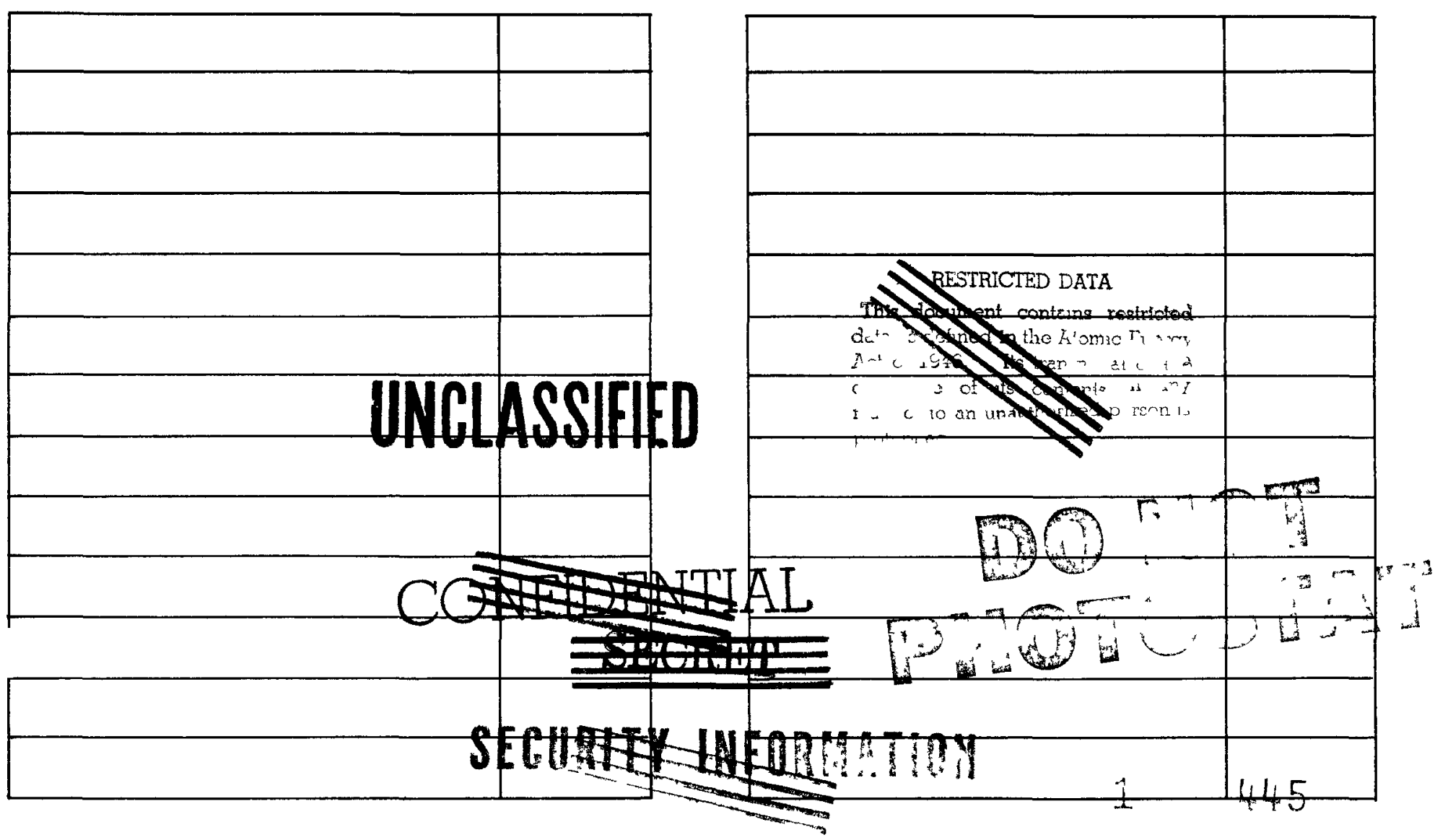

